\title{
Nostalgia experiencial de realidad y olvido del ser: la vocación metafísica de la Teología
}

Para el entrañable amigo, Jesús Encinas, O.S.A., quien a su manera me animaba y enseñaba a balbucear sobre Dios en la vida cotidiana, sobre todo en medio del sufrimiento, q.e.p.d.

¡Que mi estrella no sea la que más resplandezca sino la más lejana! ¡No me queme su lumbre sino su altura, hasta lograr que crezca la mirada en peligros del espacio y la cumbre!

C. RodrígueZ, $A$ las estrellas

Sentenciaba Heidegger: "El son del silencio no es nada humana. En cambio, el ser humano es, en su esencia, ser hablante. Esta palabra "hablante" significa aquí: llevado a su propiedad a partir del hablar del habla"1. Hay que dejarle hablar al habla.

A tenor de ello, cabe recordar que Heidegger optó por abstenerse de hablar de Dios. Dios no cabe dentro de las categorías del pensar, que es lo característico del habla, del ser lingüístico o hablante ${ }^{2}$. No es este el lugar para una exégesis de la postura heideggeriana, pero sí cabe afirmar aquí que, en efecto, el pensador friburgense apunta a Dios como aquel de que habla la metafísica en que el silencio es obligatorio yendo más allá de la diferencia entre el ser de los seres y de los entes.

El silencio no significa que Dios no exista, sino que apunta a que Dios está más allá del existir como ser de los seres o como ente. En efecto, Heidegger insiste en que la teología o hablar de Dios está más allá de la ontología, del hablar del ser de los seres. En efecto, la teología es un empeño de silencio inevitable. Heidegger, a su vez, insiste en que todavía esta-

1 M. Heidegger, Camino de campo. (Barcelona: Herder, 2003), 37.

2 M. Heidegger, Identität und Differenze (Pfullingen: Neske, 1957), 21. 
mos muy lejos para entender o conocer el verdadero significado del ser y de cómo se diferencia del ente. Es éste el único horizonte de poder hablar de Dios con sentido ${ }^{3}$.

Heidegger nos mete en un callejón sin salida: la diferencia del ser de los entes. No podemos trabajar desde un callejón sin salida. Es preciso redescubrir una salida de este impasse que es la experiencia y como ésta apunta a lo Absoluto, a lo trascendente, más allá de los juegos conceptuales en que se vio enredado el ínclito Heidegger y sus epígonos.

\section{Status Quaestionis: Reflexiones iniciales}

En verdad, la filosofía es un empeño de decir algo, incluso del silencio. La filosofía tiene una cima, que es la metafísica, que a la vez define a la mismísima filosofía como amor de la sabiduría, como amor a lo trascendente. La filosofía es libertad de la esclavitud a enredos conceptuales. La filosofía tiene que tomar al toro por los cuernos, cazar al unicornio, captar lo escurridizo al hablar y volver a su raíz a través de la experiencia que es la mediación de lo real para ser realidad y de la realidad para ser real. Sólo es posterior el acto de pensar. Primero hay que vivir, en efecto, experienciar, esto es, mediar lo real para ser realidad y la realidad para ser real; mediar lo infinito en lo finito.

La teología es la manera concreta para captar esta mediación. La teología que es hablar de Dios tiene que redescubrir su vocación metafísica en orden a poder hablar, en orden a poder llevar a cabo su cometido, más allá del habla, más allá del ser a través de la experiencia. Así se libra de la distinción odiosa y ontológica entre fe y razón, revelación y raciocinio.

La teología es un empeño que ha de entenderse en estos términos. Dejarle hablar al hablar es subir, trascender los límites del habla. Por eso, puede afirmarse que la teología es una subida a la montaña. Y esta subida impone ciertas nieblas, que traspasan las fronteras de nuestro lenguaje, de nuestro hablar. Siendo así, es una subida más allá del ser, pues el lenguaje es la frontera del ser y el ser es el horizonte del lenguaje. Mas a la vez brota de lo más íntimo, obedeciendo a las necesidades íntimas y más inefables del hombre finito y culpable que no sólo tiene nostalgia por lo Infinito sino que se siente mediado por lo Infinito en lo finito. La teología es un quehacer de profundis tenebrae 4 .

\footnotetext{
3 M. Heidegger, Über den Humanismus. (Frankfurt a.M.L: Klosterman, 1947), 19, 32-36.

${ }^{4}$ M. de Unamuno, "Del sentimiento trágico de la vida" en Idem., Obras Completas, vol. VII. (Madrid: Escelicer, 1966), 119.
} 
Más allá del lengua se abre un filón, una senda experiencial marcada por la ruptura, pues inevitablemente rompe con las imposiciones ontológicas y va directo a la realidad que se hace real o lo real que se hace realidad en su sentido absoluto. La teología encuentra a este sentido absoluto como Dios, más allá del ser y del hablar, a través del itinerario experiencial.

La absolutización ontológica, de la que padece Heidegger, ha afectado a su filosofía de tal manera que resulta seca, árida, carente de vida. La absolutización del ser ha llevado a la desaparición de la metafísica: el olvido de la experiencia que es lo jugoso, que es el río que lleva a la fuente que es lo Absoluto: lo real de la realidad y la realidad de lo real, más allá del ser, del habla y en lo más íntimo de las tinieblas. El recuerdo es siempre metafísico. La nostalgia metafísica va más allá de la severidad de los entes ensalzados como el ser de los seres. Y de esto ha hablado elocuentemente el vate Fray Luis de León:

¡Oh monte! ¡Oh fuente! ¡Oh río!

¡Oh secreto seguro, deleitoso!

Roto casi el navío

A vuestro almo reposo

Huyo de aqueste mar tempestuoso.

Un no rompido sueño,

Un día puro, alegre, libre quiero;

No quiero ver el ceño

Vanamente severo

De a quien la sangre ensalza o el dinero 5 .

El hablar es una imposición ontológica. Una imposición del ser. El lenguaje nace como transparencia del ser. Y la opacidad del ser es la demarcación de los límites del hablar. El ser es opaco por esencia. Su trasparencia, su "alétheia" sólo "ocurre" en el lenguaje ${ }^{6}$. Mejor dicho, en la realización del ser como lenguaje.

El ser marca la frontera del lenguaje, como ya queda dicho. Es la mismísima frontera del lenguaje. Heidegger decía también que en el lenguaje mora el ser. El ser, la cumbre filosófica por antonomasia, la cima de todos los ficheros de recursos filosóficos, simboliza lo que es, lo que hay, pero no

5 Fray Luis de León, "Vida Retirada I,20-30", Idem., Obras Completas, ed. de F. García (Madrid: Biblioteca de Autores Cristianos, 1959).

6 Es oportuno recordar aquí la tesis orteguiana recogida en "Orígen y epílogo" a J. Marías, Historia de la filosofía. (Madrid: Revista de Occidente, 1944) 
lo que está detrás, no lo que subyace al ser, que es la realidad, sobre todo en su instancia Absoluta. De ahí, el olvido de la realidad. A esta luz, cabe recordar estos versos enigmáticos de Léon Felipe:

"Para encontrar la verdad hay que organizar el cerebro:

Y el poeta:

Para encontar la verdad hay que reventar el cerebro, hay que hacerlo explorar. La verdad está más allá de la caja de música y del gran fichero filosófico"7.

\section{El camino desde el olvido: Historia y lenguaje de lo Absoluto}

Desde Platón, por lo menos, se ha experiementado el olvido del ser. La metafísica occidental, denominada ontoteología, ha sido tildeada de "olvido del ser". Pero en realidad, ha sido el recuerdo (anámnesis) del ser. Lo que se ha olvidado es la realidad, sobre todo lo Absoluto, que es fuente de toda realidad. Ortega, a la luz de este planteamiento, ha insistido en llamar a toda realidad, desde la radicalidad, que es la vida. Escuchémosle al respecto: "El nuevo hecho o realidad radical es nuestra vida, la de cada cual. Intente cualquiera hablar de otra realidad como más indubitable y primaria que ésta y verá que es imposible. Ni siquiera pensar es anterior a vivir, porque el pensar se encuentra a sí mismo como trozo de mi vida, como un acto particular de ella... En suma, cualquier realidad que queramos poner como primaria, hallamos que supone nuestra vida y que el ponerla es ya un acto vital, es vivir"8.

La historia es la narrativa de lo Absoluto y su dejarse experienciar, que se concretiza en la vida de la que brota el ser como trozo, como cumbre del pensamiento que inevitable es vital, pues es inevitable sentirse vivir (vivenciar o erlebnis) ${ }^{9}$. La historia se configura porque lo Absoluto se deja experienciar con rostro personal. Y este rostro personal de lo Absoluto, lo llamamos "Dios".

De ahí, "Dios", como lo Absoluto en sí con rostro (que se revela, que entra en una alianza, en una relación con el hombre), provoca un lenguaje: la teología. Es éste el lenguaje de lo Absoluto. La teología es Dios hablando de sí, no como límite, sino como centro del dinamismo de la historia, como fuerza, como espíritu. No como marcador del fracaso, sino centro

${ }^{7}$ L. Felipe, “ Libro VI: ¿Quién soy yo?” en Obras (Madrid: Ediciones Austral, s.a.).

8 J. Ortega y Gasset, Obras Completas, vol. VII. (Madrid: Alianza Editorial, 1987), 423424.

${ }^{9}$ W. Dilthey, Teoría de la concepción del mundo. (México: FCE, 1954), 82. 
experiencial siendo experiencia o mediación de sí mismo dentro de la historia, creando la narrativa de la historia. Por eso, Dios se halla en el centro de la vida, "en medio de la aldea", como le gustaba decir a Bonhoeffer ${ }^{10}$.O como dijera Zubiri en "el lugar natural de la realidad"11.

\section{Planteamientos Iniciales: God-Talk a partir de la herencia ontológica}

Dios es lo Absoluto que tiene una Palabra y que la ofrece. La ofrece "en medio de la aldea", en medio del quehacer humano así configurando imágenes, formas, figuras que constitutyen el contexto de la vivencia humana, dentro de la historia, dentro de la gran narrativa de la historia.

La teología, es ante todo, el "hablar de Dios", la Palabra de Dios ofrecida en la historia como perenne novedad conservando lo de siempre, pues Dios no cambia, pero entra en la historia cambiante del ser humano que es finito y culpable.

Desde sus raíces etimológicas, la teología (un vocablo de origen griego y por tanto, occidental) es "hablar de Dios", o como reza el título de un libro que tuvo un gran impacto en el área de los estudios religiosos y culturales durante la segunda mitad de la década de los sesenta, es "God-Talk". El autor de este libro, el teólogo anglicano recién desaparecido, John Macquarrie, inicia su obra significativa con las siguientes palabras: "Si sustiyésemos las raíces anglosajonas por las griegas, la palabra 'teología' parecería ser equivalente a 'hablar de Dios' [God-Talk]. Es una forma de discurso que pretende hablar sobre Dios"12.

De acuerdo con Macquarrie, todas las formas de hablar sobre Dios se calificarían como teología, pues reservamos este nombre para las formas más sofisticadas y reflexivas sobre Dios. Por otra parte, prosigue el ya citado autor, "se necesita muy poca sofisticación para ver que hablar sobre Dios debe ser muy diferente de hablar sobre las cosas y las personas ordinarias con que nos cruzamos en el mundo, y que a pesar de la semejanza de sus nombres, la teología debe ser algo muy diferente de la geología. Por tanto, podemos reconocer, desde ahora mismo, que la teología es más bien una clase extraña de lenguaje. Es una forma especial de hablar de Dios, y el propio hablar de Dios parece ser diferente del discurso de nuestra vida diaria

\footnotetext{
10 D. Bonhoeffer, Resistencia y sumisión. (Salmanca: Ediciones Sígueme, 1983), 198.

11 X. Zubiri Naturaleza, Historia, Dios (Madrid: Alianza Editorial, 1951), 154.

12 J. Macquarrie, God-Talk. El análisis del lenguaje y la lógica de la teología. (Salamanca: Ediciones Sígueme, 1974), 10.
} 
sobre lo que ocurre en el mundo"13. Este autor tiene muy en cuenta el fenómeno occidental de la muerte de Dios; hoy en día, en occidente, el susodicho fenómeno toma cuerpo en la llamada posmodernidad, es decir, la conciencia de que la razón no puede captar la totalidad de la realidad ${ }^{14}$.

Recientemente, un autor nos ha recordado que "el hombre desde que es hombre se ha preguntado por Dios. Esto constituye un hecho incontrovertible, una especie de consenso universal. Contra facta non valent argumenta. Gustará o no, se aceptará o se rechazará, se reputará buena o mala noticia, tiempo bien o mal empleado, se interpretará positiva o negativamente, como acierto o fatalidad desgraciada. Pero ahí está como innegable para tirios y troyanos, agnósticos y escépticos, ateos y teístas ese hecho ininterrumpido, omnipresente desde la Antigüedad remota hasta la ultimísima vanguardia posmoderna, en el estado mitológico, en el filosófico-teológico y también en el positivo (Comte), hasta el Medievo con un planteamiento prevalentemente cosmológico-objetivista y desde la Modernidad con otro decididamente antropológico-subjetivista (acceso a Dios ya no desde el cosmos, sino desde la subjetividad humana: felicidad, conciencia, verdad, amor, libertad, dolor)"15. El lector sabrá perdonarme la cita un poco larga, pero suscribo plenamente estas palabras, sobre todo a la luz de la crisis ontológica en que nos encontramos.

\section{Configurando la crisis}

Precisemos. Podría contextualizarse esta crisis dentro de dos marcos generales que de ninguna manera son fijos o definitivos. Son más bien tanteos para facilitar nuestras reflexiones en el presente ensayo. Por una parte, existe el marco en que hay una carencia, una pobreza de materia para tener una experiencia válida y duradera de Dios cuya base es la pobreza de la facultad de expresar (facultad lingüístico-artística) una experiencia de Dios, la cual hace que Dios sea real en este marco. Varios autores lo han bautizado, sin tanteos, con nombres espantosos como secularización, nihilismo,

13 Ibid.

14 Cfr. J.-F. Lyotard, La condition postmoderne: rapport sur le savoir. (París: Les Éditions Minuit, 1979); P. Anderson, The Origins of Postmodernity. (Londres: Verso, 1998); S. Connor, Postmodernist Culture. An Introduction to Theories of the Contemporary., $2^{\mathrm{a}}$ ed., (Londres: Blackwell Publishers, 1997); D. Harvey, The Condition of Postmodernity: An Inquiry into the Origins of Cultural Change. (Oxford: Oxford University Press, 1991).

15 A. de Luis Ferreras, "Sobre el pensar y Dios", en Varios, Dios en el pensamiento hispano del siglo $X X$. (Salamanca: Ediciones Sígueme, 2002), 22. 
modernismo, posmodernidad, etc. Se experimenta un vacío total debido a una fragmentación originaria en que la realidad ya no es captada, ni expresada (por consiguiente) en su totalidad o como un todo íntegro.

Por otro lado, de ahí podría deducirse que es imposible hablar de Dios puesto que este es el Ser Supremo, el garante de la totalidad. Esta totalidad se ha condensado ontológicamente como mundo: "El mundo habla el hombre y para comprender este lenguaje, basta conocer los mitos y descifrar los símbolos... En última instancia el Mundo se revela como lenguaje. Habla al hombre por su propio modo de ser, por sus estructuras y por sus ritmos"16. Sólo existen fragmentos o modos fragmentarios de hablar que sólo pueden discurrir acerca de lo fragmentario. Dentro de este contexto podria comprenderse (manipulativamente) la insistencia de algunos pensadores en que se sustituyan las categorías ontológicas por las de la presencia, imanencia o incluso la experiencia, no sólo como dato empírico relacionado con el proceso cognitivo, sino como "evento" total que implica mediación de lo trascendente (o ausente) en lo inmanente (el contexto humano) al hablar de Dios.

Conforme a la ontología, el ser es la totalidad expresada por el lenguage. Este no nos puede asegurar lo Infinito.

Dentro de lo ontológico, el occidente ha desarrollado su lenguaje sobre Dios. Esto parte del supuesto que el lenguaje capta la esencia de las cosas, incluso de lo Absoluto. Este se transmite lingüísticamente como lo universal y por lo tanto, epistemológicamente, lo verdadero.

A esta luz, queda patente que el lenguaje ontológico se ha alejado de la experiencia humana, de la categoría fundamental de todo ser humano, caracterizada por la finitud y la culpabilidad, sobre todo desde la experiencia colectiva del desgarramiento a partir de las guerras mundiales y otras catástrofes que han dejado huellas de sangre en las páginas colectivas de la historia humana ${ }^{17}$.

Por eso, la palabra "Dios" o lo Absoluto ha muerto para muchos. De hecho se le ha utilizado a Santo Tomás de Aquino en esta empresa. Me refiero sobre todo a su concepto de ens subsistens ${ }^{18}$ para afirmar que Dios necesita del ser absolutamente en orden a ser Dios. El Aquinate apuntaba con la noción de ens subsistens a una realidad más allá de lo que en la época moderna se denominaría ontología. El Aquinate hablaba de lo más allá.

\footnotetext{
16 M. Elaide, Imágenes y símbolos. (Madrid: Taurus, 1974), 13.

17 Cfr. J. Daniélou, El misterio de la historia. (San Sebastián: Dinor, 1960); A. Dondeyne, "L'historicité dans la philosophie contemporaine", en Revue philosophique de Louvain 54 (1956), 5-25; 456-477; P. Ricœur, Histoire et verité. (París: Seuil, 1958).

18 Santo Tomás de Aquino, Summa Theologiae, I, Q.3.
} 
Apuntaba a lo trascendente. De ahí también ha muerto la teología y, en efecto, la ontología.

A esta luz, es preciso clamar la renovación experiencial de la teología19. Mi ensayo, que no es exhaustivo y por lo tanto es sólo exploratorio, quiere ser ante todo filosófico, pero se mueve en un campo circunstrito y liminar, esto es, en la zona fronteriza entre teología y filosofía, desde la cual brotan las aguas de la espiritualidad que manan y corren desde la fuente de la mística o la experiencia del Misterio presente ${ }^{20}$.

De la crisis del silencio a la plenitud de la palabra:

Desde la zona del silencio

El residuo de la crisis debida al fracaso de la ontología respecto a lo teológico es el silencio. Dios se ha relegado a lo que podría denominarse la "zona del silencio".

En dicha zona se encuentra a Dios. Es imposible referirse a las cosas trascendentales dado que éstas van más allá de los límites del mundo. "Dios no se revela en el mundo", sentencia Wittgenstein en su primera etapa filosófica. Por eso, de Dios no se puede hablar. Es trascendente. No puede expresarse. Es lo inexpresable. "Simplemente se muestra, es lo místico (das mystik)." El único recurso es el silencio. "De lo que no se puede hablar es menester callarse" 21 . En efecto, parece como que el filósofo austriaco afirmara que Dios es un termino ontológico, por ello vacío (trascedente) y sin sentido. De ahí nació el movimiento llamado el "positivismo lógico"22. Tal movimiento, al declarar que hablar de Dios y la trascendencia no tiene sentido, ha declarado, en efecto, la ausencia de Dios del lenguaje humano. El lenguaje, de acuerdo con este planteamiento, es el límite del campo experiencial del hombre.

19 Cfr. sobre todo L. Gilkey, Naming the Whirlwind. The Renewal of God-Language. (Indianapolis-Nueva York: The Bobs-Merrill Company, 1969).

20 Reconozco que la lectura de los ensayos de A. Peperzak ha sido gratificante al reflexionar sobre estos temas. Me refiero a Philosophy. Between Faith and Theology. Addresses to Catholic Intellectuals. (Norte Dame: University of Notre Dame Press, 2005).

21 Estas citas lapidarias se toman de L. Wittgenstein, Tractatus logico-philosophicus. (Madrid: Revista de Occidente, 1957). No he seguido del todo la traducción benemérita de E. Tierno Galván. He tenido muy en cuenta las aportaciones del libro colectivo dirigido por I.M. Colpi y R.W. Beard, Essays on Wittgenstein's Tractatus. (Bristol: Thoemmes Press, 1993). 1986).

${ }^{22}$ Cfr. A. J. Ayer (comp.), El positivismo lógico. (México: Fondo de Cultura Económica, 
El silencio indica los límites de una experiencia a la vez que clama para que se superen dichos límites. La clave para traspasar dichos límites, contextualizados en el lenguaje y sublimados por el silencio, es la experiencia. A tenor de ello, muchos, tal vez por desesperación, han recurrido a la palabra de los místicos, testigos y maestros cualificados en este campo de ir más allá de los límites experienciales mostrado sobre todo en una renovación profunda del lenguaje y de sus límites. Dicha renovación lingüística, en efecto, significa la apertura de un nuevo mundo experiencial ${ }^{23}$ y partiendo, a la vez, del supuesto "quien no tiene a Dios en sí, no puede experimentar [verdaderamente-M.O.] su ausencia"24.

Se ha interpretado el silencio, con mucha razón, como augurio de la crisis. Dentro de la misma corriente se ha sentenciado que la mística es irracional porque es inefable, es decir, pertenence a la zona del silencio (o identificable con ella) a la cual de ninguna manera podría llegar la certidumbre del saber fundamentada por Descartes y desarrollado en la modernidad como filosofía de la subjetividad, esto es, del "sentido de sujeto" 25 , que conquista lo experimentable y cognoscible ${ }^{26}$. Por así decirlo, es, en efecto, la anihilacion de la racionalidad poscartesiana culminando en los grandes sistemas (Kant y Hegel). El silencio ha venido a señalar para muchos el fracaso de la continuidad de la realidad, es decir, la fragmentacion de la totalidad y de la identidad personal es inevitable. En efecto, el silencio pregona la muerte que es el fin de todo. El silencio ha venido a significar agotamiento total, es decir, el callejón sin salida que, en efecto, es la pobreza total y englobante.

\section{Hacia una revaloración del silencio: A partir de la crisis experiencial}

Este breve ensayo no tiene el propósito de disertar directamente sobre la mística en sí pero sí quisiera proponer, sin entrar en detalles, un camino inspirado en la senda tomada por los místicos. De entrada, es preciso entender o tomar el vocablo experiencial "crisis" como oportunidad, oportunidad

23 Cfr. mis reflexiones: Filosofía, mística, lenguaje: Desde las entrañas del espiritu. (Manila: Academia Filipina de la Lengua Española-Giraffe Books, 2008).

24 S. Weil, La pesanteur et la grâce. (París: Plon, 1948), 93ss. También merece la pena reflexionar con M. de Certaeau, L'absent de l'historie. (París: Mame, 1973).

25 P. Lucien Marie, L'expérience de Dieu. Actualité du message de Saint Jean de la Croix. (París: Ed. du Cerf, 1968), 144-145.

$26 \mathrm{Me}$ han estimulado intelectualmente las reflexiones sobre el dualismo cartesiano de M. Henry, Filosofía y fenomenología del cuerpo. (Salamanca: Ediciones Sígueme, 2007), 195216. 
para la creatividad, para la renovación de la tradición, de la herencia, del patrimonio común para hacerlo hablar a nuestros días dentro del contexto de la búsqueda interminable por el sentido de la realidad. En efecto, una actitud positiva en el comienzo de nuestra renovación experiencial. No debemos limitarnos a las implicaciones negativas del silencio. No debemos reducir la riqueza del silencio a una pobreza arraigada en nuestros prejuicios y preferencias por lo estrepitoso y aparatoso.

Viene bien, a estas alturas de nuestras reflexiones, prestar atención a las siguientes palabras llenas de unción de F. Rella: "Pero este silencio es una gran palabra. El silencio muestra, exhibe sin residuos lo místico. Es pues símbolo, palabra plena y sin arrugas, que se sustrae a la crítica y al análisis, defendiendo también la realidad de la cual se plantea como expresión. El silencio deviene, como el cuento kafkiano, el 'guardián delante de la puerta de la ley'....El sentimiento del místico que se abre a los límites del mundo de los hechos propone de nuevo la división clásica entre saber y sentir, entre ciencia y experiencia que es constitutiva -fundamento- de la racionalidad poscartesiana"27.

A la vez es preciso reconocer que comúnmente la crisis o situación del occidente respecto al hablar de Dios se entiende es el resultado de un agotamiento creativo. Es decir, lo que entendemos por crisis es en realidad un malestar psicológico creativo; de repente el hombre vio que sus capacidades creativas no pueden compararse con los de tiempos atrás (los denominados clásicos). Ello tiene sus raíces en la acusación humana dirigida a la realidad. Esta acusación consiste en alegar que la realidad no se da experiencialmente tan generosamente como antes. También esta realidad es percibida como escurridiza.

En mi opinión, estas acusaciones tienen su raíz en lo ontológico. La ontología no es la metafísica, sino que es más bien la reducción de lo trascendente al sistema. $Y$ éste es la reducción de la realidad al entendimiento humano, a las categorías intelectuales.

En realidad, esta reducción hizo que la realidad, en su riqueza inagotable, se deslizara de las manos del hombre. La ontología, en su pretensión hacia la totalidad o universalidad, es suma pobreza. La ontología ha reducido a la experiencia a un dato en el proceso gnoseológico y en efecto, ha reducido a la realidad al sistema.

27 F. Rella, El silencio y las palabras. El pensamiento en tiempo de crisis. (BarcelonaBuenos Aires-México: Ediciones Paidos, 1992), 22-23. 
Todo ello le ha brindado una excusa al hombre de hoy, sobre todo en el campo del arte y de la creatividad. Esta excusa puede resumirse en los siguientes términos: lo actual no puede compararse con lo clásico, lo clásico no puede repetirse. Por eso, el hombre que el está condenado a vivir, experienciar y expresarse fragmentariamente, en una especie de arte generalmente denominado kitsch o unas formas creativas nihilistas hasta inaugurar épocas, que ahora están en boga, que señalan el fin de las grandezas (con el prefijo "post"), hasta la locura extrema de sobreañadir a una serie interminable del prefijo "post" a un "post" inicial antepuesto al adjetivo para indicar la superación (por ejemplo: "post-postmoderno", "post-postestructuralismo", "post-postimpresionismo").

Pese a todo ello, pienso que subyace a estos nuevos movimientos artísticos el afán intenso o la pretensión vertiginosa de encontrar nuevas formas de expresión, nuevas formas de pensar críticas, deprimidas y deprimentes, agónicas, etc. Mas la clave para solucionar este estancamiento o impasse ha de ser el reconocimiento de lo trascendente en la obra del arte 28.

Discurrir sobre el hablar de Dios en nuestros días es un auténtico reto sobre todo desde el contexto que hemos visto anteriormente. Frente a Dios existen varias actitudes y junto a las mismas hay un número casi ilimitado de variaciones, matizaciones y precisiones. Dicho de otra manera, Dios ha sido objeto de tergiversación, estudios de laboratorio, reflexiones personales, expresiones artísticas e incluso de la indiferencia y negación muy generalizadas sobre todo en las llamadas generaciones " $\mathrm{x}$ ", " $\mathrm{y}$ ", $\mathrm{y}$ " $\mathrm{z}$ ".

$\mathrm{El}$ siglo $\mathrm{XX}$, con su horizonte de la violencia e incertidumbre, ha sido un tiempo fructífero en la historia del pensamiento respecto a Dios. Es difícil resumir o por lo menos delimitar con precisión todas las tendencias y acontecimientos ocurridos. Incluso los consabidos esquemas consignados por los más renombrados historiadores del pensamiento no son adecuados para enmarcar la diversidad aludida.

Cabe señalar, a este respecto, la llamada actitud "existencialista" en que la negación de Dios significa libertad para el hombre (Freud, Sartre) o la reducción de Dios como un ente entre los demás en favor de la búsqueda por el ser (Sein) de los seres (Heidegger). En las postrimerías del siglo XIX, colectivamente se oyeron los martillazos de la muerte de Dios (Gott ist tot) y el nacimiento del übermensch (Nietzsche). En medio de esta muerte, se preocupó por la inmortalidad de Dios y el anhelo por dicha inmortalidad se identificó con el anhelo de Dios (Unamuno). Junto a ello, brotó una

28 Cfr. G. Steiner, Real Presences. (Chicago-Londres: University of Chicago Press, 1989). 
nueva y fuerte corriente atea, llamada por un autor "eclipse de Dios" (Buber) predominante en el occidente. Quizá el siglo XXI es el siglo de la espera (attente) de Dios (Weil).

Pero si se hace desde otra orilla es una oportunidad creativa. En vez de atemorizarnos por la "crisis" deberíamos, a mi juicio, buscar las raíces del hablar de Dios, que es la experiencia y de la que han hablado los místicos.

Muchos ríos de tinta ya se han derramado para discernir si es posible hablar de Dios -más o menos teniendo en cuenta la crisis en el sentido convencional. Esos escritos ciertamente tienen sus méritos y han de servir como punto de arranque para nuevas investigaciones como la nuestra.

Nos interesa más bien el sentido originario del hablar de Dios: la sabiduría detrás de este hablar, su verdadera naturaleza, su raíz escondida.

De verdad, se ha producido la muerte de la tradición; la tradición ontológica es un fracaso. Desde su pretensión originaria, que consistía en convertir la realidad en sistema y en reducir la experiencia a un dato gnoseológico, ya tenía el destino de fracasar. Desde el principio ya era un fracaso. El único exitazo de un fracasado consiste en fracasar.

Por lo menos, la muerte de la tradición ontológica ha ocasionado la búsqueda incesante de nuevas formas. Estas han nacido del reconocimiento que la absolutización del ser ha convertido al mismísimo ser en la cáscara de nuestro lenguaje y de nuestra capacidad crítica en lugar de elevarlo a una categoría originaria y omnipresente en toda actividad especulativa e incluso práctica. En este sentido, no debería extrañarnos la insistencia de pensadores como Levinas, quienes han sobrevivido a la tiranía del ser, en la necesidad de ir más allá de la ontología ${ }^{29}$. Efectivamente, es esta una llamada al desprendimiento de lo ontológico ${ }^{30}$, es decir, desprenderse de la nada, viéndolo como nada en orden a abrazar el verdadero Todo ${ }^{31}$.

Mediante la ontología, el pensamiento humano ha confundido al Dios verdadero y vivo con los ídolos del pensamiento humano hechos concretos en la cultura, matriz de toda actividad especulativa y práctica.

En oriente, por ejemplo, en particular en Japón, surgió el Zen y su insistencia en la muerte de Dios; es decir, la muerte de las formas tradicionales (convencionales) de hablar de Dios, de adorarlo para descubrir el gran vacio, la gran nada (Satori o Nirvana en el budismo tradicional). En los Vedas, los

29 Cfr. E. Levinas, Totalidad e Infinito. Ensayo sobre la exterioridad, $2^{\mathrm{a}}$ ed. (Salamanca: Ediciones Sígueme, 1987).

30 Cfr. Meister Eckhart, Deutsche predigten und traktate. (Múnich: J. Quint, 1963).

31 Véanse mis reflexiones: "Todo-Nada: Revaloración mistagógico-pedagógica de la valoración sanjuanista", en Studium 45 (2005), 263-276. 
sabios han convertido en estribillo "neti, neti, neti" o ni esto ni siquiera esto. En el occidente, se ha llegado al extremo de la teología apofática o negativa del Pseudo-Dionisio. Todo ello es un llamamiento a ir más allá de las categorías del pensamiento sistemático que es la ejecución ontológica.

Otro ejemplo a tener en cuenta, en filipino (tagalo), no existe una palabra que equivalga al "ser" (on, ens, sein, being, être, ser, essere), pese a intentos de algunos autores filipinos de traducirlo albergando buenas intenciones pero traicionando lo verdaderamente filipino. Más bien el filipino insiste en lo trascedente, en lo metafísico (en el "hiwaga" o misterio que va más allá de cualquier ontologización). Hablan los filipinos de la realidad como "totoo", esto es, lo verdadero o la verdad en sí. Hablan de la experiencia como "karanasan" no como dato empírico, sino como evento, como mediación en que se da el "mahiwaga" que se identifica con lo Absoluto. Aunque se puede hablar de "bagay" (objetos o cosas) o "mayroon" (hay o lo que hay), estos, aunque se los puede señalar con el dedo, no deben entenderse, esforzadamente, como traducciones ontológicas de la palabra "ser" -que en efecto es un concordismo ontológico de la herencia intelectual y espiritual de los filipinos-, sino como despliegues de la verdad o de lo verdadero (como "totoo" o "katotohan"), que se experiencia (como "karanasan") y no simplemente se experimenta. En filipino o tagalo, hay un vocablo que significa "nada", que es "wala", que en otros lenguajes, como por ejemplo, el cebuano significa negación. En la lengua filipina no hay totalidad ontológica, sino una plenitud metafísica "captada" experiencialmente como "mahiwaga", como Misterio, como Presencia, como "nandayan" en una tautología no exacta, sino que señala lo más allá de las fronteras del todo ontológico, del "lahat". Si bien, léxicamente no es muy rica la lengua filipina, posee una riqueza verdadermanete metafísica que va más allá de los límites ontológicos que se enroscan en juegos lexicales y perífrasis idiomáticas. De hecho, en filipino se dice "higit sa lahat" que no es simplemente "sobre todo", sino "más allá del todo". En efecto, así se señala la plenitud más allá de la palabra reducida al ser ${ }^{32}$. Es la Palabra Originaria que se hizo carne, que se hizo Presencia (y no simplemente presente).

\footnotetext{
$32 \mathrm{He}$ de confesar que originalmente se me ha pedido un ensayo sobre el pensamiento filipino. En vez de hablar del pensamiento filipino o abogar lo que podría denominarse "filosofía filipina", he optado por filosofar, siendo filipino y utilizando mi formación recibida tanto en oriente como en occidente. Pienso que todo se ha hecho hasta el momento en pro de la llamada filosofía filipina no pasa de ser antropología cultural o sociología lingüística. En mi opinión, los que han llegado al nivel estrictamente filosófico han tergiversado el espíritu filipino por sus motivaciones ontológicas.
} 
La plenitud de la palabra consiste en la superación de cualquier pretensión ontológica y trascender hacia lo metafísico. Los filósofos y teólogos que han desarrollado sus labores bajo el patrocinio de la ontología piensan que han dado en el blanco de Dios, sin darse cuenta de que el hombre es el verdadero blanco de Dios.

\section{El camino experiencial: La clave para la renovación de la teología}

La experiencia es ante todo mediación de lo Absoluto en su trascendencia en la historicidad finita y culpable del hombre inmanente. Es un "evento" que permite la presencia, presencia de lo ausente (trascendente) en lo inmanente creando así la historia, la narrativa de la presencia.

La teología, en orden a renovarse, debería nutrirse de esta noción de la experiencia y cultivarla en su reflexión. De esta manera, la teología no sólo se entendería "hablar de Dios", conceptualización ésta sumamente pobre, sino que sería lo que verdaderamente es desde el principio: "Dios habla". Mejor dicho, es Dios quien habla porque es la Presencia en sí, ofrecida como Misterio, experienciado desde la finitud y culpablidad de la inmanencia humana en la que se escribe la narrativa de la misma Presencia en sí.

El Misterio no es una categoría, sino que es la manera como el hombre capta a Dios siendo Presencia en sí, tras la ausencia del Ser Supremo de la ontología, que es la fabricación del sistema, es decir, del entendimiento totalizante. El Misterio es presencia de lo Infinito en lo finito.

Como dejamos dicho, este ensayo no trata de la mística o de los místicos en sí pero hay que reconocer que la clave para la renovación verdaderamente metafísica (y no ontológica) de la teología la tienen los místicos, quienes en palabras de G. Bruno, "por estar avezados a ser más capaces para la contemplación y por estar naturalmente dotados de un espíritu lúcido e intelectivo... agudizan los sentidos por medio del fuego del deseo y el hálito de la intención, y, con el aliento de la cogitativa facultad, encienden la luz racional, con la cual ven más allá de lo ordinario; y éstos no vienen al fín a hablar como receptáculos o instrumentos, sino como principales artífices y eficientes"33.

Los místicos reconocen que "la última profundidad de lo humano es realmente sagrado y trascendente" 34 . De ahí, los místicos han indagado

\footnotetext{
33 G. Bruno, Los heroicos furores. (Madrid: Ed. Tecnos, 1987), 56-57.

34 Son estas palabras luminosas de A. Blanch, El espíritu de la letra. Acercamiento creyente a la literatura (Madrid: Ed. PPC, 2002), 153.
} 
sobre la relación entre lo Absoluto y lo finito y culpalble, entre lo finito y lo infinito, no para prometer totalidades o postular universalidades, sino para reclamar la Presencia en sí en medio de las presencias superficiales que vienen a ser ausencias o vacíos o noches oscuras tanto individuales como colectivas.

Dios, que es lo Absoluto experienciado siendo Persona, y que es Misterio en su presencia en el horizonte finito, en su trascendencia se oculta pero está dispuesto, desde la eternidad, a darse por Amor en su trascendencia, es decir, se deja experienciar, mediar en su infinitud no para ser reducido al Ser o al sistema sino para hacerse visible en las más variadas configuraciones de lo finito en la historia, que se contextualiza en la cultura, que a mi parecer, posee las siguientes dimensiones fundamentales: a) como narrativa global o parcial o historia; b) como camino confesional de la religación institucional o privada o religión; c) como actuación individual o colectiva o libertad; y d) como convivencia comunitaria o política.

En la experiencia, lo Absoluto en sí se revela como Dios y no como el ser. Se revela como Dios, en clave relacional: para ser Padre, Hijo y Espíritu Santo, en la tradición cristiana, invitando al hombre a una relacionalidad participativa. Así se experienciará la realidad en su fuente, en toda su riqueza inagotable.

Los místicos no han querido ser sistematizadores o reductores sino testigos, profetas (portavoces), discípulos formados para ser amigos íntimos (en el lenguaje místico esta amistad se ha denominado como relación filial y esponsal) en orden a ser maestros o iniciadores en la dinámica experiencial de la Realidad en sí (mistagogos).

$Y$ todo ello lo han realizado arraigando el lenguaje en la experiencia y realizando el despliegue del mismo lenguaje en un juego o ejecución que se desliza en los momentos de lo próximo y lo lejano, de lo oculto y de lo manifiesto, liberando toda pretensión humana de la ambición inhumana de conquistar el universo mediante el saber (reduciéndolo todo a sistemas que son las configuraciones estructurales del ser) a una comunión más profunda traspasando los límites del sistema, las fronteras de la pretensión hacia el saber absoluto.

El saber absoluto es reducirlo todo a representaciones, al conocer. En efecto, la ontología es una teoría del conocimiento a través del lenguaje, que es la esencia del ser. Consiste en crear representaciones para abrir sistemas o reducciones de la realidad por ser real al ser, patente desde por lo menos Kant y culminando en Hegel. El filósofo malogrado M. Foucault resume todo esto con palabras llenas de unción. Séame permitido citarlo a continuación: "Frente a esta abertura sobre lo trascendental y simétricamente a 
ella, otra forma de pensamiento se plantea la pregunta por las condiciones de una relación entre las representaciones por el lado del ser mismo que se encuentra representado en ellas: lo que, en el horizonte de todas las representaciones reales, se indica de suyo como fundamento de su unidad son estos objetos nunca objetivables, estas representaciones jamás representables del todo, estas visibilidades manifiestas e invisibles a la vez, estas realidades que se retiran en la medida misma en que son fundamentadoras de lo que se da y se adelanta hasta nosotros: el poder del trabajo, la fuerza de la vida, el poder de hablar. A partir de estas formas que rondan en los límites exteriores de nuestra experiencia, el valor de las cosas, la organización de los vivientes, la estructura gramatical y la afinidad histórica de las lenguas llegan hasta nuestra representación y nos solicitan la tarea, quizá infinita, del conocimiento... La nueva positividad de las ciencias de la vida, del lenguaje y de la economía están en correspondencia con la instauración de una filosofía trascendental" 35 .

El resultado es la plenitud de la Presencia en su inagotabilidad de la que podemos beber para proseguir con nuestros esfuerzos colectivos en orden a mejorar las condiciones de nuestra convivencia. La Presencia es el encuentro de lo infinito y lo finito, de lo Absoluto y lo no-absoluto.

Precisemos. Esta Presencia se presenta como Misterio, la mediación experiencial de lo trascendente en lo inmanente creando una historia, una narrativa experiencial que aspira a poseer carácter soteriológico, ungiendo a los hombres con el bálsamo santificador de la participación de lo finito en lo infinito.

No podemos seguir bebiendo de pozos secos o empobrecidos, que ha dado lugar a nuestra pobreza compartida ${ }^{36}$. Esta, a su vez, es la raíz de nuestro egoísmo, de nuestras tendencias destructivas o nihilistas hechas concretas en la guerra, en la corrupción, en el hambre, en el terrorismo, etc. Nuestros pozos se han secado por nuestro reduccionismo ontológico cuyas promesas totalizantes son carentes de verdadero significado y más bien vacías.

De hecho, estas mismas promesas son parasíticas, pues nos han robado de la riqueza, sin que nos demos cuenta, de nuestra aspiración a lo trascendente, es decir, de nuestra vocación metafísica que es innata. Ser hombre es ser metafísico por vocación porque el hombre es experiencia de Dios, es manera finita de ser Dios, como gusta decir a Zubiri37.

\footnotetext{
35 M. Foucault, Las palabras y las cosas. (México: Siglo XXI Editores, 1991), 239.

36 Reconozco la inspiración de G. Gutiérrez, Beber en su propio pozo (Salamanca: Ediciones Sígueme, 1993).

37 X. Zubiri, El hombre y Dios. (Madrid: Ed. Alianza, 1984).
} 
Reducción teológica a "hablar de Dios" y caminos de redescubrimiento

Reducir la teología a un mero "hablar de Dios", por muy sofisticado que sea, como demuestra la historia de la teología (desde Platón y Aristóteles, pasando por Plotino, Pseudo-Dionisio, Agustín, Anselmo, Buenaventura, Tomás de Aquino, y de manera especial también por Ignacio de Loyola, Fray Luis de León, Teresa de Jesús, Juan de la Cruz, Juan Bautista de la Concepción, a los nombres más próceres de nuestra época como Guardini, Rahner, Schillebeeckx, Chenu, Congar, Von Balthasar, Barth, Bultmann, Tillich, Pannenberg, Arintero, Garrigou-Lagrange, Xiberta, Ramírez, Cuervo, Alfaro, De Lubac, Daniélou, Vaggagani, Marsili, Küng, Bandera, Pikaza etc.), es nada menos que robarle la voz a lo Absoluto, quien debe hablar, quien se deja experienciar en su infinitud, con rostro, esto es, como Persona, como Dios ${ }^{38}$.

El Dios ontológico está encerrado en fórmulas humanas o conceptos y no con "su misma realidad viviente. A esta luz, cabe citar a una voz autorizada quien ha visto en el hablar místico o espiritual un gran valor teológico, más allá de lo meramente ontológico. Me refiero al Cardenal Congar: "En cuanto a la ontología, ellos (los espirituales-M.O.) conservan la de la relación del ser espiritual con la realidad y con la verdad de Dios; no con un Dios tal como está encerrado en las fórmulas humanas, sino con su misma realidad viviente. Su ontología, de ningún modo es óntica, es la de la relación espiritual entre el hombre y Dios, realizada en el hombre por su acción soberana. Responde a una antropología espiritual interpretado por completo dentro de su relación con la acción divina, recibida en ellos"39. Se refiere este autor a la mística (lo recibido). Y lo que se recibe es el mismísimo principio metafísica (la acción divina) en toda su dinamicidad.

Es, en efecto, una actitud ontológica (que en realidad es óntica, conforme a la terminología empleada por Congar) que ha producido el silencio atroz, sobre todo en medio de los momentos más álgidos de nuestra narrativa compartida como Auschwitz o las torres gemelas de Nueva York o la estación de Renfe en Madrid o la guerra en Iraq con la crisis global económica tras estas guerras.

\footnotetext{
38 Con agudeza, afirma G. Scholem diferencia el Dios de Plotino (y en efecto, el Dios de los filósofos griegos) del Dios de la Persona afirmando que aquél carece del carácter personal, ver: "La lutte entre le Dieu de Plotin et le Dieu de la Bible dans la Kabbale ancienne", en Idem., Le Nom et les symboles de Dieu dans la mystique jive. (París: Editions du Cerf, 1983), 19-21.

39 Y. Congar, "Lenguaje de los espirituales y lenguaje de los teólogos", en Idem., Situación y tareas de la teología hoy (Salamanca: Ediciones Sígueme, 1970), 181.
} 
Pero con la muerte del dios ontológico, es decir, la superación de la ontología el hombre se encuentra en la intemperie experiencial que clama el regreso del Dios verdadero y vivo en la experiencia, como experiencia, como Dios que se hace mediación, que se hace encontradizo. Y este camino lo han descubierto los místicos partiendo de la Encarnación que es el Misterio clave por el que Dios se hace Misterio constante en nuestra historia, sin reducirse óntica u ontológicamente.

La teología posee una vocación metafísica que brota de profundis tenebrare, de lo que Cassirer ha llamado con acierto "conciencia religiosa" 40 . Es por su naturaleza metafísica. Sólo en la metafísica la teología llegará a su sobrenaturaleza innata. Consiste ésta en dejarle hablar a Dios, en dejarnos amar por Él sabiendo que nuestro hablar nunca podría agotarlo. Lo mejor sería dejarlo hablar, dejarlo dejarse experienciar tal como es, más allá de nuestras pretensiones ontológicas y sistemáticas.

De esta manera, su Presencia permanecerá en nosotros, en nuestra narrativa experiencial pese a los males que nos acompañan en el viaje que consiste en transformar en nuestro ser ahí (Dasein) o existencia en ser ahí para alguien y para algo. Y esto es vivir, vivir para alguien, es decir, vivir "metafísicamente", que es igual que vivir "místicamente", pues es vivir para Dios, quien mora en nosotros en su trascendencia pese a nuestra finitud y culpabilidad ${ }^{41}$. 